\title{
Effects of long-term moderate hypercapnia on acid-base balance and growth rate in marine mussels Mytilus galloprovincialis
}

\author{
Basile Michaelidis ${ }^{1, *}$, Christos Ouzounis ${ }^{1}$, Andreas Paleras ${ }^{1}$, Hans O. Pörtner ${ }^{2}$ \\ ${ }^{1}$ Laboratory of Animal Physiology, Department of Zoology, Faculty of Science, School of Biology, Aristotle University \\ of Thessaloniki, 54006 Thessaloniki, Greece \\ ${ }^{2}$ Alfred-Wegener-Institut für Polar-und Meeresforschung, Ökophysiologie und Ökotoxikologie, Postfach 120161, \\ 27515 Bremerhaven, Germany
}

\begin{abstract}
In the context of future scenarios of progressive accumulation of anthropogenic $\mathrm{CO}_{2}$ in marine surface waters, the present study addresses the effects of long-term hypercapnia on a Mediterranean bivalve, Mytilus galloprovincialis. Sea-water $\mathrm{pH}$ was lowered to a value of 7.3 by equilibration with elevated $\mathrm{CO}_{2}$ levels. This is close to the maximum $\mathrm{pH}$ drop expected in marine surface waters during atmospheric $\mathrm{CO}_{2}$ accumulation. Intra- and extracellular acid-base parameters as well as changes in metabolic rate and growth were studied under both normocapnia and hypercapnia. Long-term hypercapnia caused a permanent reduction in haemolymph $\mathrm{pH}$. To limit the degree of acidosis, mussels increased haemolymph bicarbonate levels, which are derived mainly from the dissolution of shell $\mathrm{CaCO}_{3}$. Intracellular $\mathrm{pH}$ in various tissues was at least partly compensated; no deviation from control values occurred during long-term measurements in whole soft-body tissues. The rate of oxygen consumption fell significantly, indicating a lower metabolic rate. In line with previous reports, a close correlation became evident between the reduction in extracellular $\mathrm{pH}$ and the reduction in metabolic rate of mussels during hypercapnia. Analysis of frequency histograms of growth rate revealed that hypercapnia caused a slowing of growth, possibly related to the reduction in metabolic rate and the dissolution of shell $\mathrm{CaCO}_{3}$ as a result of extracellular acidosis. In addition, increased nitrogen excretion by hypercapnic mussels indicates the net degradation of protein, thereby contributing to growth reduction. The results obtained in the present study strongly indicate that a reduction in sea-water $\mathrm{pH}$ to 7.3 may be fatal for the mussels. They also confirm previous observations that a reduction in sea-water $\mathrm{pH}$ below 7.5 is harmful for shelled molluscs.
\end{abstract}

KEY WORDS: Hypercapnia - Ocean $\mathrm{CO}_{2}$ accumulation - Marine bivalve $\cdot$ Acid-base balance Growth rate $\cdot$ Oxygen consumption $\cdot$ Metabolic depression

\section{INTRODUCTION}

Global warming and its impact on ecosystems has stimulated considerable scientific interest. It is widely believed that the current increase in atmospheric carbon dioxide $\left(\mathrm{CO}_{2}\right)$ (by $31 \%$ in relation to pre-industrial levels; Houghton et al. 2001) is the main cause of global warming. Since $\mathrm{CO}_{2}$ rapidly equilibrates with the surface ocean, increased $\mathrm{CO}_{2}$ levels in the atmosphere would cause an increase in sea-water $\mathrm{pCO}_{2}$ (partial pressure of $\mathrm{CO}_{2}$ ) with a concomitant decrease in sea-water $\mathrm{pH}$. An estimated reduction in sea water down to $\mathrm{pH} 7.3$ is expected within the next $300 \mathrm{yr}$ (Caldeira \& Wilckett 2003). Such a reduction in seawater $\mathrm{pH}$ at elevated $\mathrm{pCO}_{2}$ might impact on physiological processes in marine organisms. Moreover, in the light of potential future scenarios of deep-sea $\mathrm{CO}_{2}$ injections as a means of controlling atmospheric $\mathrm{CO}_{2}$ levels (Lackner 2003), it also becomes essential to understand the impact of $\mathrm{CO}_{2}$ accumulation on the physiology of marine organisms. A recent report on the environmental impacts of ocean disposal of $\mathrm{CO}_{2}$ shows 
that marine organisms can only temporarily tolerate any $\mathrm{pH}$ reduction below 7.0, and, if feasible, a level of water $\mathrm{pH}$ below 7.5 should be avoided (Ormerod \& Angel 1996).

Elevated environmental $\mathrm{pCO}_{2}$ values cause $\mathrm{CO}_{2}$ to enter the organisms and their body fluids and tissues by diffusion. This occurs especially in those aquatic animals that lack well-developed circulatory and ventilatory systems and depend solely on a favourable tissue-to-environment gradient for $\mathrm{CO}_{2}$ excretion. Elevated extra- and intracellular $\mathrm{pCO}_{2}$ values result in decreased extra- and intracellular $\mathrm{pH}$ levels. Physiological responses of marine animals from shallow waters to intra- and extracellular hypercapnia have been well characterized, as $\mathrm{CO}_{2}$ exposure has been instrumental in physiological studies of acid-base regulation (Roos \& Boron 1981, Somero 1985, Cameron 1986, 1989, Truchot 1987, Heisler 1989, Walsh \& Milligan 1989).

Three main mechanisms are involved in the regulation of acid-base balance: (1) metabolic production and consumption of protons, (2) buffering of intra- and extracellular compartments, and (3) active protonequivalent ion transport. Buffering of extra- and intracellular fluids is mainly achieved by an increase in the level of bicarbonates, which are formed by passive buffering, by net proton release, and, in bivalves and other calcified animals, by the dissolution of $\mathrm{CaCO}_{3}$ exoskeletons (Lindinger et al. 1984). While the latter mechanism can facilitate the compensation of a temporary acid-base disturbance, long-term exposure to elevated $\mathrm{CO}_{2}$ levels might be fatal if such levels are sufficient to hamper shell formation. However, the feedback of $\mathrm{CO}_{2}$-induced disturbances in acid-base equilibria on processes other than calcification as, for example, growth has only rarely been addressed.

Growth is a physiological process, which might be significantly decelerated under long-term exposure of marine animals to increased $\mathrm{CO}_{2}$ levels. Recent work has shown a close linkage between $\mathrm{pH}$ conditions in the field and clam growth rates (Ringwood \& Keppler 2002). Moreover, Shirayama (2002) demonstrated that even very moderate increases in $\mathrm{CO}_{2}$ of $200 \mathrm{ppm}$ above present levels caused a reduction in growth rate and survival of echinoderms and gastropods, indicating that long-term $\mathrm{CO}_{2}$ changes may be affecting growth of calcifying organisms. Moreover, metabolic depression is, in many cases, an adaptation strategy put in place to survive hypercapnia (Guppy \& Withers 1999). A limitation in energy turnover might lead to a reduction in protein synthesis, which would by definition restrict both growth and reproduction. Low $\mathrm{pH}$ levels can have a significant reducing effect on protein synthesis in aquatic animals (Kwast \& Hand 1996, Reid et al. 1997, Langenbuch \& Pörtner 2002).
To our knowledge, very few studies addressed the impacts of long-term exposure of marine animals, especially bivalves, to moderately elevated $\mathrm{CO}_{2}$ levels. The present paper aspires to contribute to such investigations, by reporting analyses of possibly interdependent changes in acid-base balance, oxygen consumption, nitrogen excretion and growth rate in the Mediterranean bivalve Mytilus galloprovincialis. Since, as reported above, a sea-water $\mathrm{pH}$ below 7.5 might have critical effects, all mussels were kept under hypercapnic conditions set to cause a sea-water $\mathrm{pH}$ of 7.3. The $\mathrm{pH}$ value chosen is close to the maximum $\mathrm{pH}$ drop expected in marine surface waters during business-as-usual scenarios of anthropogenic $\mathrm{CO}_{2}$ production and release (Caldeira \& Wickett 2003).

\section{MATERIALS AND METHODS}

Animals. Juvenile and adult specimens of Mytilus galloprovincialis used for the purposes of the present study were collected in the area of Halastra in the Thermaikos Gulf, Greece. Juveniles were held in aquaria, each containing $200 \mathrm{l}$ of aerated recirculating natural sea water, for $5 \mathrm{~d}$ prior to experimentation. Water temperature was controlled at $18 \pm 0.5^{\circ} \mathrm{C}$ and salinity at $32 \pm 3.5 \%$. Adults were kept in aquaria under the same conditions for $2 \mathrm{wk}$ prior to experimentation. Sea-water $\mathrm{pH}$ was about $8.05 \pm 0.02$.

Studies of mussels growth rate under normoxia and normoxic hypercapnia. To study the growth rate of mussels, juveniles ranging from 5 to $25 \mathrm{~mm}$ body length were used. Mussels were divided in 2 groups, which had about the same distribution of size frequency, and were put in 2 similar tanks (A and B), each containing 2001 of aerated recirculating sea water. Tank A was used as a control, while hypercapnia was imposed in Tank B. Gaseous $\mathrm{CO}_{2}$ provided from a $\mathrm{CO}_{2}$ cylinder was injected into the sea water through a magnetic valve connected to a $\mathrm{pH}$ monitor and a $\mathrm{pH}$ electrode exposed to the sea water in Tank B. The $\mathrm{pH}$ meter was set to a value of 7.3, and $\mathrm{pH}$ was controlled at $\pm 0.05 \mathrm{pH}$ units. Sea water was continuously air bubbled through a separate line connected to an air pump, and $\mathrm{pO}_{2}$ in the sea water was monitored by a Radiometer E5046 $\mathrm{pO}_{2}$ electrode. $\mathrm{pCO}_{2}$ and the level of bicarbonate in the sea water were determined as described below. Conditions under which normoxic and hypercapnic juveniles and adult mussels were kept are summarized in Table 1.

The juvenile mussels were kept under normoxia and normoxic hypercapnia for 3 mo and were fed an algal paste consisting of Isochrysis sp. and Chlorela sp. All mussels were fed a ration of $30 \mathrm{mg}$ total particular matter (TPM) $\mathrm{l}^{-1} 4$ times $\mathrm{d}^{-1}$ every $2 \mathrm{~d}$. 
Table 1. Physicochemical conditions of sea water where mussels were kept under normoxia and normoxic hypercapnia

\begin{tabular}{|lcc|}
\hline Conditions & Normoxia & Normoxic hypercapnia \\
\hline $\mathrm{pH}$ & $8.05 \pm 0.02$ & $7.3 \pm 0.03$ \\
$\mathrm{pCO}_{2}\left(\mathrm{~mm} \mathrm{Hg}^{-}\right)$ & $0.82 \pm 0.09$ & $3.82 \pm 0.53$ \\
$\mathrm{HCO}_{3}^{-}\left(\mathrm{mmol} \mathrm{l}^{-1}\right)$ & $2.34 \pm 0.13$ & $2.89 \pm 0.38$ \\
$\mathrm{pO}_{2}\left(\mathrm{~mm} \mathrm{Hg}^{2}\right)$ & $>145$ & $>145$ \\
$\mathrm{Ca}^{2+}\left(\mathrm{mmol} \mathrm{l}^{-1}\right)$ & $17.45 \pm 0.09$ & $17.89 \pm 0.054$ \\
\hline
\end{tabular}

Mussel growth was recorded at regular time intervals in juveniles. During each sampling occasion a sample of 100 mussels was taken at random from the tanks and their shell growth as well as their total body weight was measured. For the analysis of shell growth, shell length $(L)$, shell width $(W)$ and shell height $(H)$ were measured. From each of the above samples a subsample of about 30 to 40 mussels was used for weight determinations. The mussels were dried on filter paper and weighed. The shells were separated from the body, dried on filter paper to remove excess water, and weighed to the nearest $0.001 \mathrm{~g}$. Dry weights were recorded after drying to constant weight in an oven at $70^{\circ} \mathrm{C}$.

Size-frequency histograms were constructed for each sampling using shell length (SL) as the most reliable morphometric parameter for shell growth. The class interval used for the construction of the histograms was $5 \mathrm{~mm}$ and was determined by Goulden's method (in Cancela da fonseca 1965).

Oxygen consumption and ammonia excretion under normoxia and normoxic hypercapnia. The rate of oxygen consumption was determined for juvenile and adult mussels under normocapnia and hypercapnia in a closed respirometer system. Changes in $\mathrm{pO}_{2}$ were monitored by a Radiometer E5046 $\mathrm{pO}_{2}$ electrode fixed in a respiration chamber of $200 \mathrm{ml}$. All determinations were performed at $18^{\circ} \mathrm{C}$. Rates of oxygen consumption were determined for adults exposed to hypercapnia for $0,5,10$ and $20 \mathrm{~h}$. Before each determination of oxygen consumption, mussels were scrubbed clean and were left for $1 \mathrm{~h}$ in the chamber filled with normoxic, normocapnic filtered (0.2 $\mu \mathrm{m}$ membrane) sea water ( $\mathrm{pH}$ 8.05) or hypercapnic filtered sea water ( $\mathrm{pH}$ 7.3). Then the system was closed and changes in $\mathrm{pO}_{2}$ were monitored for $1 \mathrm{~h}$. Water samples were taken at the beginning and at the end of this period and were analysed for ammonia as described by Bergmeyer et al. (1986). For juvenile mussels, oxygen consumption was determined after exposure to hypercapnic conditions for 0, 15, 30 and $90 \mathrm{~d}$. The procedure for oxygen consumption was the same as described for adult mussels. Comparisons were carried out with corresponding controls (normoxic mussels) sampled at the same time intervals as the hypercapnic specimens.
Acid-base parameters. Determination of acid-base parameters was performed in growing juveniles and in adults kept under the same conditions of normoxia and hypercapnia. In the growing mussels intracellular $\mathrm{pH}\left(\mathrm{pH}_{\mathrm{i}}\right)$ only was determined (see below) in the whole soft body, since it was very difficult to collect haemolymph and to separate tissues after dissection. In control and hypercapnic adults levels of extracellular $\mathrm{pH}\left(\mathrm{pH}_{\mathrm{e}}\right), \mathrm{pCO}_{2}$, bicarbonate $\left(\left[\mathrm{HCO}_{3}{ }^{-}\right]_{\mathrm{e}}\right)$ as well as $\mathrm{pH}_{\mathrm{i}}$ of mantle, gills, foot, posterior adductor muscle (PAM) and anterior byssus retractor muscle (ABRM) were determined after $0,0.5,1,2,4$ and $8 \mathrm{~d}$ of hypercapnia.

Samples of haemolymph were collected by pericardiac puncture according to Fyhn \& Costlow (1975) and immediately analyzed for $\mathrm{pH}_{\mathrm{e}}$ and total $\mathrm{CO}_{2}\left(C_{\mathrm{CO}_{2}}\right)$ as described below. The remaining haemolymph samples were frozen and kept in liquid nitrogen until extracellular calcium levels $[\mathrm{Ca}]_{\mathrm{e}}$ were determined. Tissues were excised, blotted dry and freeze-clamped and kept in liquid nitrogen until used for the determination of $\mathrm{pH}_{\mathrm{i}}$.

Determination of extracellular $\mathrm{pH}, \mathrm{C}_{\mathrm{CO}_{2}}, \mathrm{pCO}_{2}, \mathrm{pO}_{2}$ and $\mathrm{Ca}^{2+}$ in haemolymph and water: The $\mathrm{pH}$ of the haemolymph $\left(\mathrm{pH}_{\mathrm{e}}\right)$ was measured at $18^{\circ} \mathrm{C}$ using a Radiometer glass capillary $\mathrm{pH}$ electrode (G299A A, BMS Mk2) calibrated with Radiometer precision buffers. $C_{\mathrm{CO}_{2}}$ was determined according to the method of Cameron (1971) using a Radiometer $\mathrm{pCO}_{2}$ electrode (E5037) calibrated with known concentrations of $\mathrm{NaHCO}_{3}$. Haemolymph $\mathrm{pCO}_{2}$ was calculated by the modified version of the Henderson-Hasselbalch equation:

$$
\mathrm{pCO}_{2}=C_{\mathrm{CO}_{2}} /\left(10^{\mathrm{pH}-\mathrm{pK}} \times \alpha \mathrm{CO}_{2}+\alpha \mathrm{CO}_{2}\right)
$$

where $\alpha \mathrm{CO}_{2}$ is the solubility of $\mathrm{CO}_{2}$. Values for the solubility and the apparent dissociation constant under physiological conditions were calculated according to Heisler (1986). The levels of bicarbonate in the haemolymph $\left(\left[\mathrm{HCO}_{3}{ }^{-}\right]_{\mathrm{e}}\right)$ were calculated from the $\mathrm{C}_{\mathrm{CO}_{2}}$ according to the equation:

$$
\left[\mathrm{HCO}_{3}^{-}\right]_{\mathrm{e}}=\mathrm{C}_{\mathrm{CO}_{2}}-\left(\alpha \mathrm{CO}_{2} \times \mathrm{pCO}_{2}\right)
$$

The level of $\mathrm{Ca}^{2+}$ in the haemolymph was determined by atomic absorption, as described by Jokumsen \& Fyhn (1982).

$\mathrm{pO}_{2}$ in the haemolymph was determined by means of a thermostatted $\left(18^{\circ} \mathrm{C}\right)$ Radiometer $\mathrm{O}_{2}$ electrode connected to a Radiometer acid-base analyzer. The $\mathrm{pO}_{2}$ electrode was calibrated at $18^{\circ} \mathrm{C}$ with Radiometer precision buffers.

Similar procedures were followed in order to determine acid-base parameters of sea water. 
Determination of intracellular $p H\left(p H_{i}\right)$ : The $\mathrm{pH}_{\mathrm{i}}$ of tissues was determined by the homogenate method developed by Pörtner et al. (1990). Tissue samples were ground under liquid nitrogen, and $100 \mathrm{mg}$ of tissue powder was added to an Eppendorf vial containing $200 \mathrm{\mu l}$ ice-cold medium (160 $\mathrm{mmol}^{-1}$ potassium fluoride, $1 \mathrm{mmol} \mathrm{l}^{-1}$ nitrilotriacetic acid, $\mathrm{pH}$ 7.4). After completely filling the vial with medium, the mixture was briefly stirred with a needle, in order to release air bubbles, then mixed on a Vortex mixer, and finally centrifuged for $30 \mathrm{~s}$. Within 3 min after thawing of the tissue powder in the medium, the $\mathrm{pH}$ of the supernatant was measured using a Radiometer glass capillary pH electrode (G299A). This value approximates $\mathrm{pH}_{\mathrm{i}}$ with an experimental error of less than $0.01 \mathrm{pH}$ units (Pörtner et al. 1990).

Determination of extracellular (haemolymph) buffer values: The non-bicarbonate buffer value $\left(\beta_{\mathrm{NB}}=-\Delta\left[\mathrm{HCO}_{3}{ }^{-}\right]_{\mathrm{e}} / \Delta \mathrm{pH}_{\mathrm{e}}\right)$ of haemolymph was determined by $\mathrm{CO}_{2}$ equilibration at $18^{\circ} \mathrm{C}$ in an intermittently rotating cuvette (tonometer model 273, Instrumentation Laboratory), which was flushed with humidified $\mathrm{CO}_{2}$ gas mixtures (between 0.2 and $1 \%$ ) in air at $18^{\circ} \mathrm{C}$. The samples of haemolymph were tonometered for $25 \mathrm{~min}$ for full equilibration and were subsequently analyzed for $\mathrm{pH}$ and $\mathrm{C}_{\mathrm{CO}_{2}}$ as described above.

Statistical analyses. Changes over time were tested for significance at the $5 \%$ level by using 1 -way analysis of variance (ANOVA) and by performing the Bonferroni post-hoc test for group comparisons. Values are presented as means $\pm \mathrm{SE}$ throughout.

\section{RESULTS}

The effect of hypercapnia on shell growth is shown in size-frequency histograms (Fig. 1). Control shell length increased progressively and ranged between 25 and $40 \mathrm{~mm}$ within $90 \mathrm{~d}$, with a maximum frequency between 25 and $30 \mathrm{~mm}$. A similar pattern of shell length growth was observed in hypercapnic mussels. However, shell growth was slower in hypercapnic mussels and, after a period of $90 \mathrm{~d}$, their shell length ranged between 10 and $35 \mathrm{~mm}$. In the latter case, mussels ranging between 20 and $25 \mathrm{~mm}$ were predominant. The plot derived from the means of shell-length and fresh-weight increments for both controls and hypercapnic mussels indicates a lower rate of shell growth in the latter (Fig. 2). Moreover, the relationship between dry weight and shell length reflected an exponential regular growth rate in both controls and
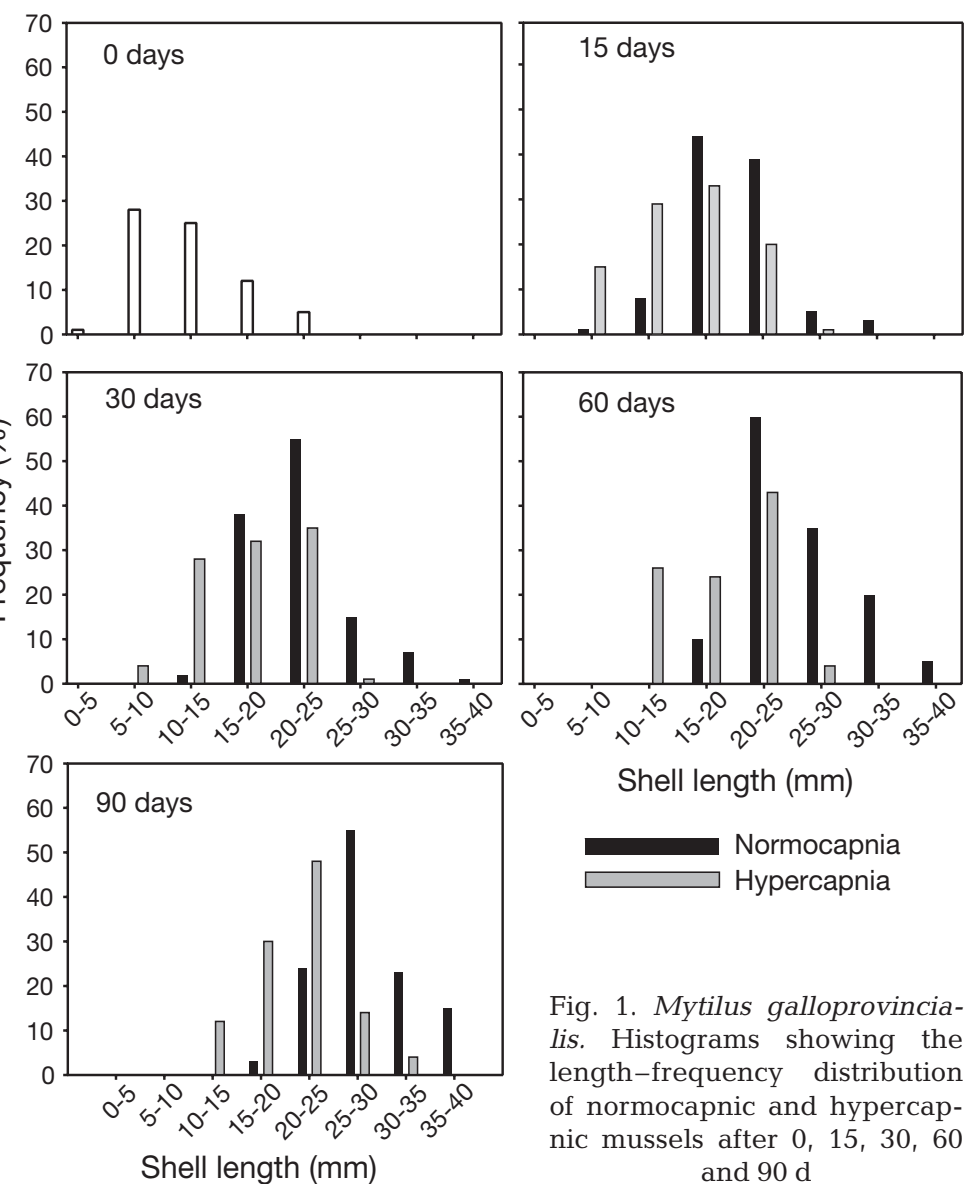

Shell length $(\mathrm{mm})$

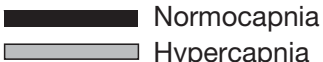

Fig. 1. Mytilus galloprovincialis. Histograms showing the length-frequency distribution of normocapnic and hypercapnic mussels after $0,15,30,60$ and $90 \mathrm{~d}$

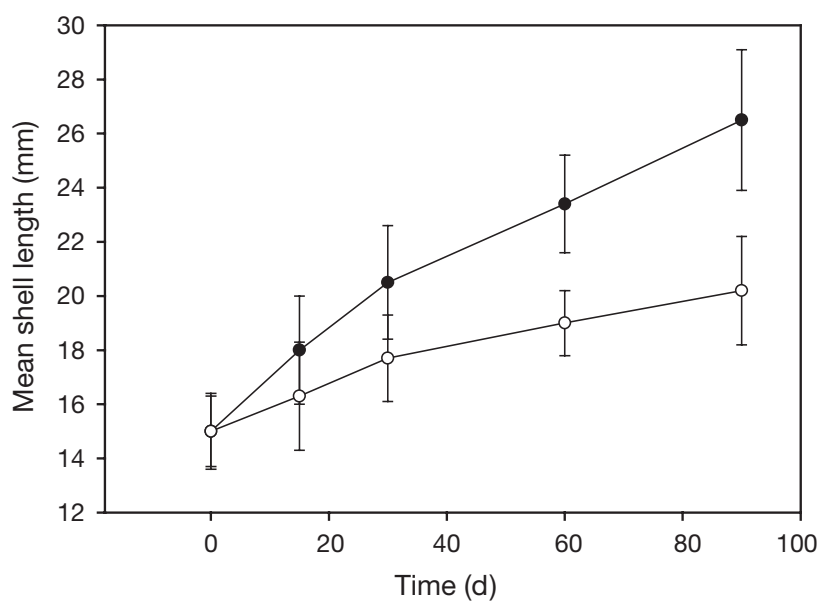

Fig. 2. Mytilus galloprovincialis. Mean shell lengths of normocapnic (•) and hypercapnic (o) mussels

hypercapnic mussels. The dry-weight-shell-length relationship was not statistically different between controls and hypercapnic mussels (Fig. 3). Similarly, the relationships between other morphometric characters, such as dry weight and shell width or dry weight and shell height, showed no statistical differences between the 2 groups of mussels (data not shown). This 

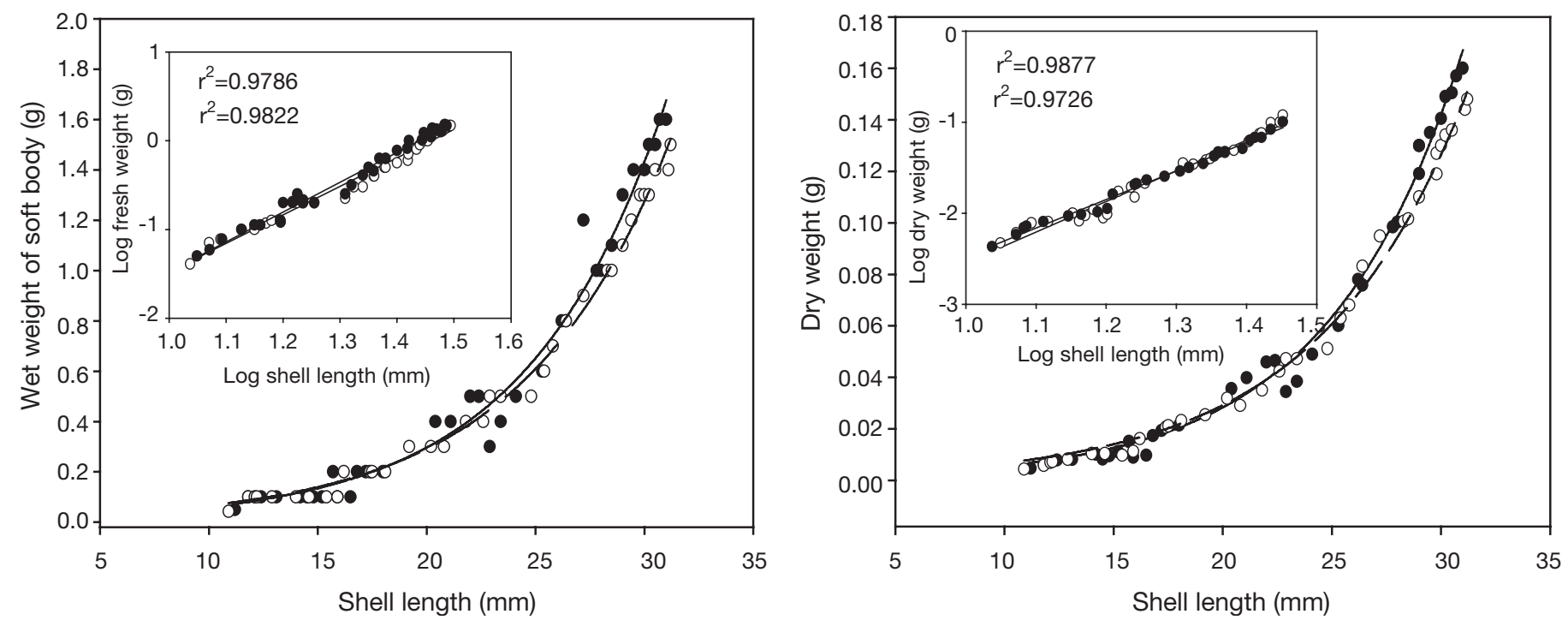

Fig. 3. Mytilus galloprovincialis. Relationships of the morphometric characteristics weight (fresh and dry) and shell length in growing mussels during normocapnia (solid line - •) and hypercapnia (dashed line - o)

comparison suggests that reduced shell growth goes hand in hand with decreased growth of soft-body tissues under hypercapnia.

The time course of changes in extracellular acidbase status in adult mussels is depicted in Fig. 4. Control extracellular acid-base parameters at time 0 (before the onset of hypercapnia) were $\mathrm{pH}=7.55 \pm$ $0.02, \mathrm{pCO}_{2}=1.15 \pm 0.21 \mathrm{~mm} \mathrm{Hg}$ and $\left[\mathrm{HCO}_{3}{ }^{-}\right]=1.62 \pm$
$0.12 \mathrm{mmol} \mathrm{l}^{-1}$. During the first $2 \mathrm{~d}$ of hypercapnia, $\mathrm{pH}_{\mathrm{e}}$ decreased from $7.55 \pm 0.02$ to $7.36 \pm 0.05$ and remained more or less constant thereafter (Fig. 4a). Haemolymph $\mathrm{pCO}_{2}$ increased from $1.15 \pm 0.21$ to $3.92 \pm 0.20 \mathrm{~mm} \mathrm{Hg}$ within the first $4 \mathrm{~d}$. After $8 \mathrm{~d}$ it reached a value of $4.35 \pm$ $0.30 \mathrm{~mm} \mathrm{Hg}$ (Fig. 4b). The pattern of changes in $\left[\mathrm{HCO}_{3}{ }^{-}\right]_{\mathrm{e}}$ was similar to those of $\mathrm{pCO}_{2}$ in haemolymph. $\left[\mathrm{HCO}_{3}{ }^{-}\right]_{\mathrm{e}}$ increased almost linearly within the first $4 \mathrm{~d}$ (from $1.62 \pm 0.12$ to $3.45 \pm 0.16 \mathrm{mmol} \mathrm{l}^{-1}$ ). After $8 \mathrm{~d}$ it reached a value of $4.01 \pm$ $0.20 \mathrm{mmol} \mathrm{l}^{-1}$ (Fig. 4c). Within the first $4 \mathrm{~d}$ the level of haemolymph [Ca] increased from $17.45 \pm 2.13$ to $26.05 \pm 1.50 \mathrm{mmol} \mathrm{l}^{-1}$. After $8 \mathrm{~d}$ it found to be $27.45 \pm 2.55 \mathrm{mmol} \mathrm{l}^{-1}$ (Fig. 4d). $\mathrm{pO}_{2}$ was determined to be $52.03 \pm$ $6.89 \mathrm{~mm} \mathrm{Hg}$ in the haemolymph of controls. Hypercapnia did not cause any change in the level of $\mathrm{pO}_{2}$.

The changes in acid-base variables in the haemolymph of Mytilus galloprovincialis during exposure to hypercapnic conditions are depicted in a $\mathrm{pH}_{\mathrm{e}}-\left[\mathrm{HCO}_{3}^{-}\right]_{\mathrm{e}}$ diagram (Fig. 5) in relation to the non-bicarbonate buffer line, $\beta_{\mathrm{NB}}$ (solid line), for haemolymph. The $\beta_{\mathrm{NB}}$ of the haemolymph was determined to be $0.65 \pm 0.1$ Slykes. The diagram shows that after an initial phase $(0.5$ to $1 \mathrm{~d})$ of uncompensated respiratory acidosis, an accumulation of bicarbonate more or less fully compensated for the rise in $\mathrm{pCO}_{2}$ and prevented a further decrement in $\mathrm{pH}_{\mathrm{e}}$.

The effect of hypercapnia on $\mathrm{pH}_{\mathrm{i}}$ is shown in Fig. 6. In control adult mussels, the $\mathrm{pH}_{\mathrm{i}}$ was found to be $7.17 \pm 0.04$ in the mantle,
Fig. 4. Mytilus galloprovincialis. Acid-base parameters and $\mathrm{Ca}^{2+}$ levels in the haemolymph of hypercapnic adult mussels. $\mathrm{N}=15$ determinations on separate preparations from different animals. Asterisks indicate the values significantly different from the control value $(0 \mathrm{~d})$ 


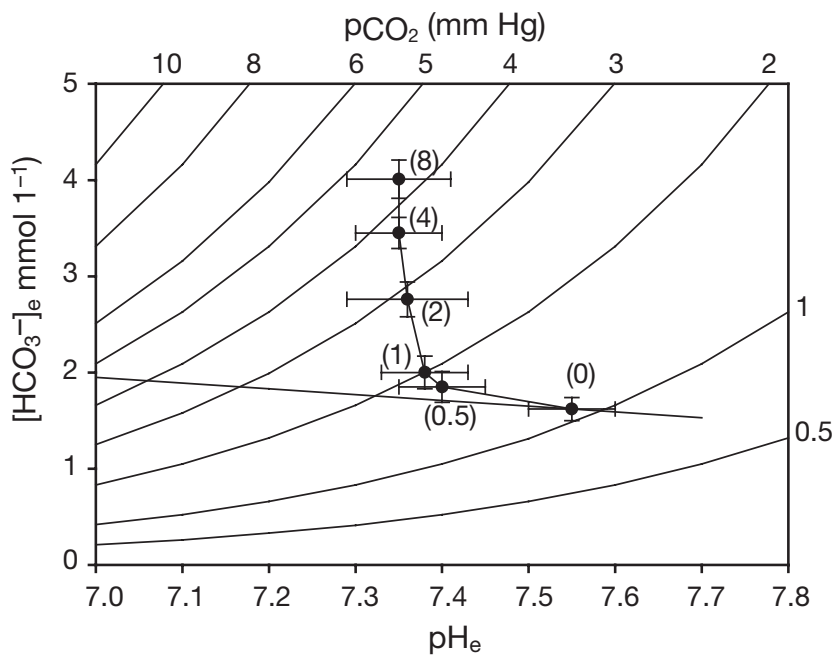

Fig. 5. Mytilus galloprovincialis. Changes in extracellular (haemolymph) acid-base status of adult mussels during hypercapnia presented in a $\mathrm{pH}_{\mathrm{e}} /\left[\mathrm{HCO}_{3}{ }^{-}\right]_{\mathrm{e}}$ diagram and in relation to the buffer line (solid line measured in vitro). The numbers in parentheses indicate the days of hypercapnia
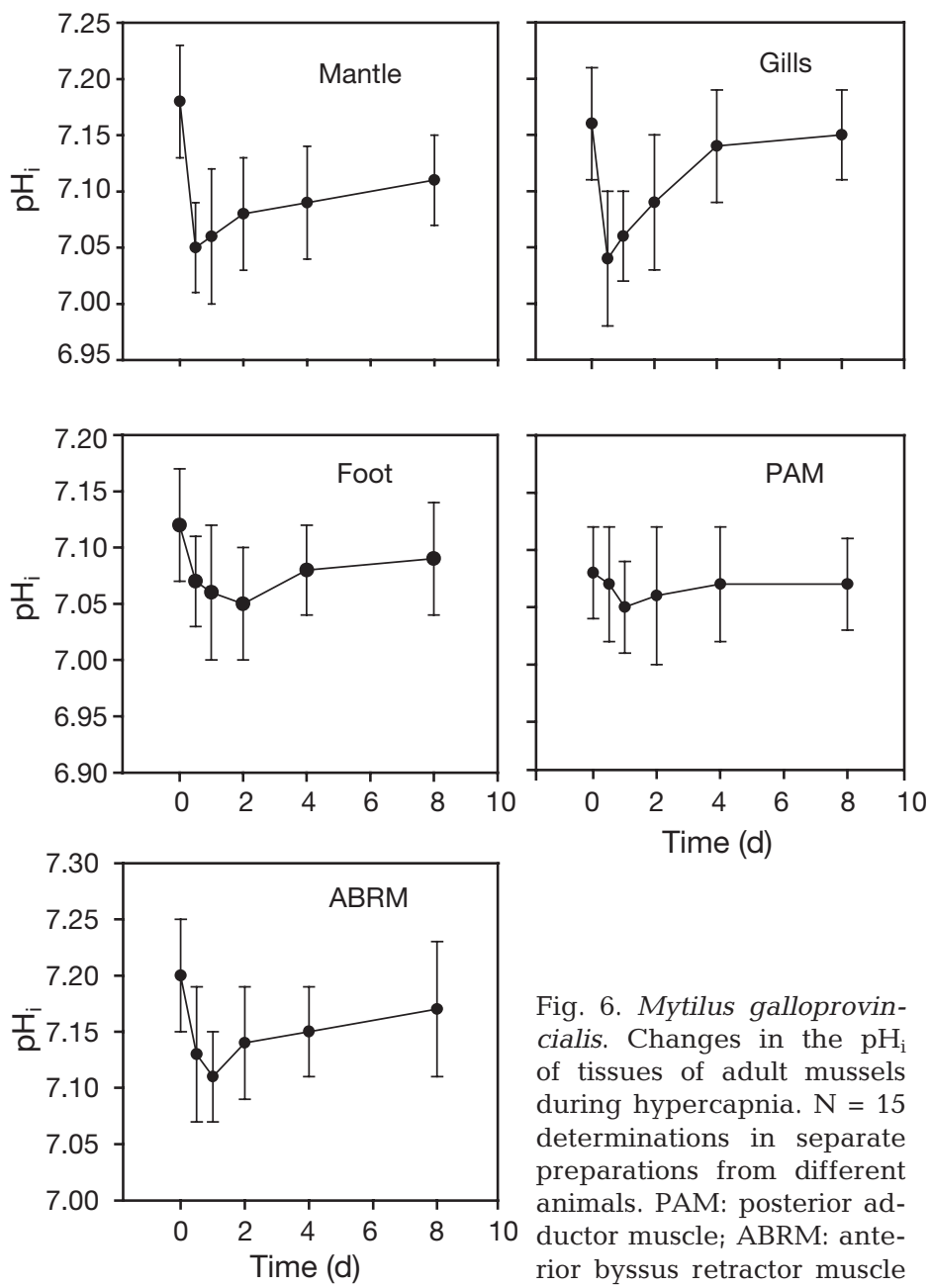

Fig. 6. Mytilus galloprovincialis. Changes in the $\mathrm{pH}_{\mathrm{i}}$ of tissues of adult mussels during hypercapnia. $\mathrm{N}=15$ determinations in separate preparations from different animals. PAM: posterior adductor muscle; ABRM: anterior byssus retractor muscle
$7.16 \pm 0.05$ in the gills, $7.12 \pm 0.05$ in the foot, $7.07 \pm$ 0.04 in the posterior adductor muscle (PAM) and $7.20 \pm$ 0.04 in the anterior byssus retractor muscle (ABRM). The pattern of $\mathrm{pH}_{\mathrm{i}}$ change was similar in all tissues during hypercapnia. $\mathrm{pH}_{\mathrm{i}}$ declined within the first day and recovered to close to control levels thereafter. It must be pointed out, however, that the decline of $\mathrm{pH}_{\mathrm{i}}$ was more evident in mantle and gills than in the muscular tissues, likely due to higher buffer values in the muscle tissues. With respect to $\mathrm{pH}_{\mathrm{i}}$ measured in the whole soft body of juvenile mussels, the results indicate that the initial $\mathrm{pH}$ disturbance remained fully compensated and that hypercapnia did not cause significant $\mathrm{pH}_{\mathrm{i}}$ fluctuations within $90 \mathrm{~d}$ (Fig. 7).

The results obtained by closed-system respirometry revealed that exposure to hypercapnia caused a significant reduction in oxygen consumption by adult Mytilus galloprocincialis (Fig. 8a) and in growing juveniles (Fig. 9). The rate of oxygen consumption was reduced to $35 \%$ of control levels after $20 \mathrm{~h}$ of exposure to hypercapnic conditions in adults and to $65 \%$ in juveniles. In contrast, the rate of ammonia excretion into sea water increased by $60 \%$ (from 0.71 to $1.12 \mathrm{mEq} \mathrm{l}^{-1}$ ) within the first $5 \mathrm{~h}$ of hypercapnia in adults (Fig. 8b). Thereafter it remained constantly elevated above the value seen during $20 \mathrm{~h}$ of exposure to control conditions (Fig. 8b).

\section{DISCUSSION}

Similarly to data obtained in other marine bivalves, hypercapnia caused a marked respiratory acidosis in extracellular fluids, resulting in a permanent reduc-

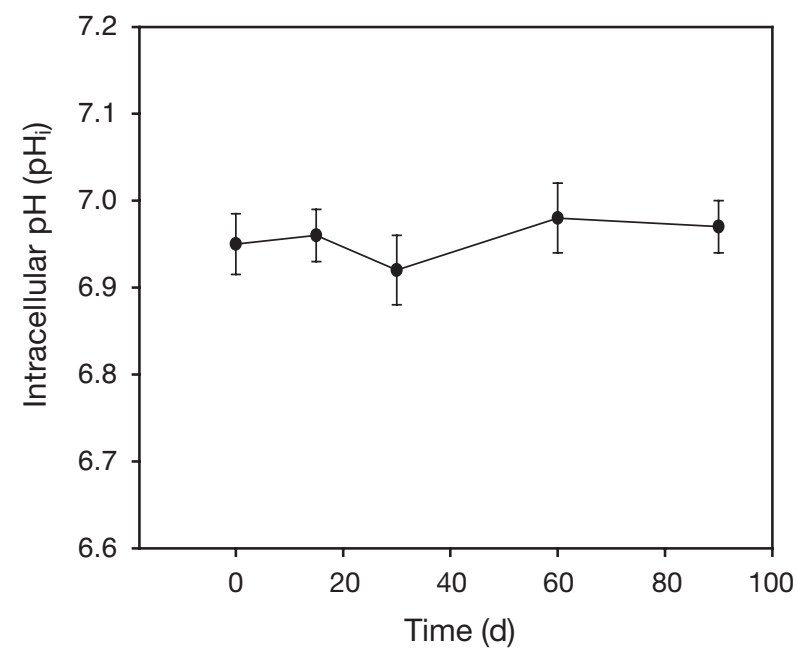

Fig. 7. Mytilus galloprovincialis. Changes in the $\mathrm{pH}_{\mathrm{i}}$ of the soft body of growing mussels after exposure to hypercapnia for $0,15,30,60$ and $90 \mathrm{~d}$. $\mathrm{N}=15$ determinations on separate preparations from different animals 

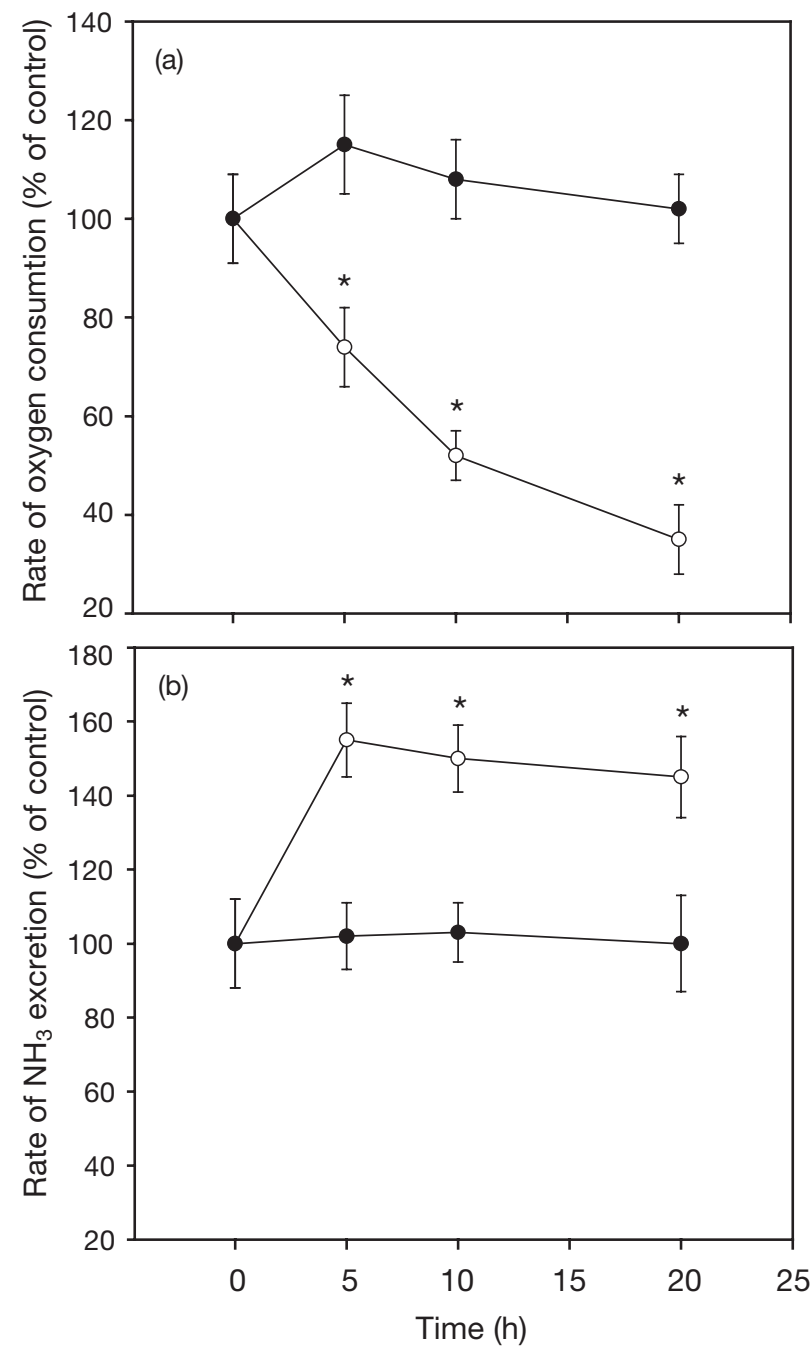

Fig. 8. Mytilus galloprovincialis. Changes in (a) oxygen consumption (o) and (b) ammonia release (o) of adult mussels after exposure to hypercapnia for $0,5,10$ and $20 \mathrm{~h} . \mathrm{N}=10$ determinations in separate preparations from different animals. Asterisks indicate the values significantly different from the control value $(\bullet)$

tion of $\mathrm{pH}_{\mathrm{e}}$ from $7.55 \pm 0.02$ to $7.36 \pm 0.05$ (Fig. $4 \mathrm{a}$ ). Acid-base parameters were found similar in the present study of Mytilus galloprovincialis as in those reported for M. edulis (Booth et al. 1984). However, Lindinger et al. (1984) reported a $\mathrm{pH}_{\mathrm{e}}$ value which was 0.3 lower in $M$. edulis controls, likely due to the stress caused by DMO $\left(5,5\right.$-dimethly $\left[{ }^{14} \mathrm{C}\right]$ oxazoline2,4-dione) infusion (DMO was used to analyse intracellular $\mathrm{pH}_{i}$ Walsh et al. 1984). Similar to findings by Lindinger et al. (1984) in M. edulis, respiratory acidosis in M. galloprovincialis elicits an accumulation of bicarbonates in extracellular fluids to compensate for the acidosis (Fig. 4c). In contrast to observations in fish, where the extracellular acidosis is frequently fully compensated (Heisler 1986), bicarbonate accumula-

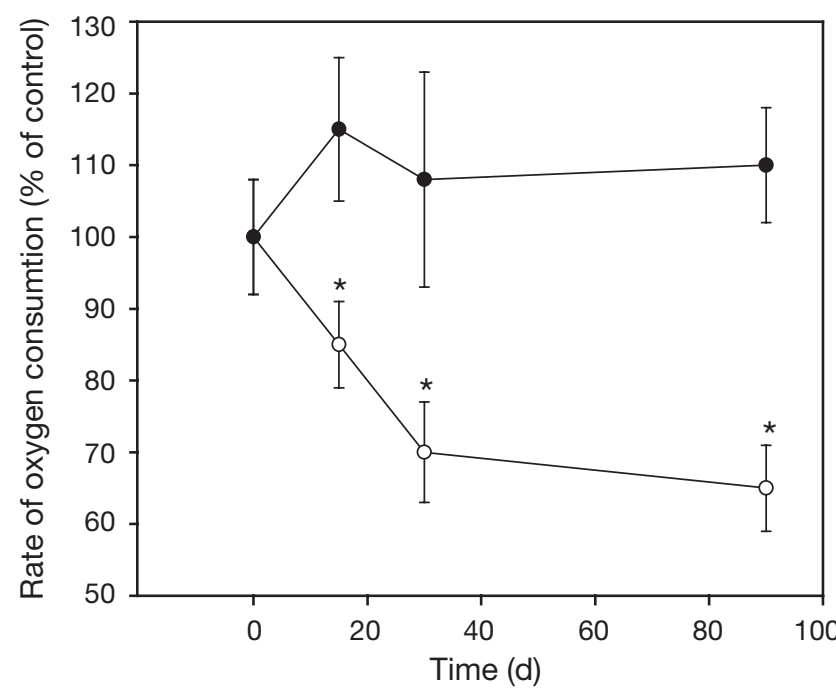

Fig. 9. Mytilus galloprovincialis. Changes in oxygen consumption of growing juvenile mussels after exposure to hypercapnia (o) for $0,15,30$ and $90 \mathrm{~d}$. $\mathrm{N}=10$ determinations in separate preparations from different animals. Asterisks indicate the values significantly different from the control value $(\bullet$

tion in mussel haemolymph occurred at a reduced steady-state value of extracellular $\mathrm{pH}$. This may be a common phenomenon in lower marine invertebrates and was also seen in a sipunculid worm, Sipunculus nudus (Pörtner et al. 1998). As reported in the case of $M$. edulis (Lindinger et al. 1984), shell dissolution seems to be the main source of bicarbonates in M. galloprovincialis, indicated by the more than equimolar increase in $\mathrm{Ca}^{2+}$ levels in extracellular fluids (Fig. 4d).

Although $\mathrm{pH}_{\mathrm{e}}$ levels remained reduced throughout hypercapnia (Fig. 4a), $\mathrm{pH}_{\mathrm{i}}$ dropped initially but was restored within the first $2 \mathrm{~d}$; thereafter, it was maintained close to control levels in all 4 tissues analysed (Fig. 6). This conclusion is supported by the long-term analysis of $\mathrm{pH}_{\mathrm{i}}$ in the whole soft body of juveniles. Complete compensation for the intracellular acidosis was not observed in Mytilus edulis during more severe hypercapnia of $\mathrm{pCO}_{2}=26 \mathrm{~mm} \mathrm{Hg}$ (Lindinger et al. 1984). Perhaps this observation is not only due to the severity of hypercapnia but also to the limited duration $(24 \mathrm{~h})$ of the hypercapnic exposure in the study by Lindinger et al. (1984). According to our results, mussels are able to fully restore $\mathrm{pH}_{\mathrm{i}}$ levels when they are exposed to moderate hypercapnia (water $\mathrm{pCO}_{2}=3.82$ $\pm 0.53 \mathrm{~mm} \mathrm{Hg}$ and water $\mathrm{pH} \mathrm{7.3)}$. The preferential compensation of $\mathrm{pH}_{\mathrm{i}}$ at only partially compensated extracellular $\mathrm{pH}$ was also observed in the sipunculid worm exposed to long-term hypercapnia (Pörtner et al. 1998). In the sipunculid it appeared that full compensation of the intracellular acidosis depended on extracellular accumulation of bicarbonate. The patterns observed in the present study would be in line with this 
conclusion. Previous results also emphasize a dependency of $\mathrm{pH}_{\mathrm{i}}$ on the degree of hypercapnia and on $\mathrm{pH}_{\mathrm{e}}$ (Zange et al. 1990, Reipschläger \& Pörtner 1996). To support $\mathrm{pH}_{\mathrm{i}}$ regulation, some animals, including M. edulis, are able to shift steady-state levels of bicarbonate to higher values according to the degree of hypercapnia. The final steady-state value of their $\mathrm{pH}_{\mathrm{e}}$ results as a function of the acid-base characteristics of the medium (Lindinger et al. 1984, Cameron \& Iwama 1989, Heisler 1989).

Although control values of $\mathrm{pH}_{\mathrm{i}}$ were successfully reestablished and maintained constant during long-term hypercapnia (Fig. 7), elevated $\mathrm{CO}_{2}$ levels caused a decrease in the rate of oxygen consumption in juvenile and adult mussels (Figs. 8a \& 9), clearly indicating a drastic reduction in metabolic rate. A number of studies conducted on several invertebrates have shown that hypercapnia alone is capable of eliciting depressed metabolic rates (Barnhart \& McMahon 1988, Barnhart 1989, Rees \& Hand 1990). Metabolic suppression is, in many cases, an adaptive strategy for survival under transiently stressful conditions. Low $\mathrm{pH}$ levels and hypercapnia can trigger metabolic depression in many organisms (Guppy \& Withers 1999), possibly because oxygen and $\mathrm{CO}_{2}$ levels are often inversely correlated in aquatic habitats (Truchot \& Duhamel-Jouve 1980). The fact that $\mathrm{pO}_{2}$ levels in the haemolymph of adult mussels were maintained during hypercapnia excludes a contribution of hypoxia and indicates not only that mussels remained aerobic during hypercapnia but also that hypercapnia alone elicited metabolic depression. This is similar to recent findings in Sipunculus nudus (Pörtner et al. 1998). Metabolic depression is frequently discussed to be associated with a decrease in $\mathrm{pH}_{\mathrm{i}}$, which inhibits activities of many enzymes involved in intermediary metabolism (Somero 1985). Moreover, low $\mathrm{pH}_{\mathrm{i}}$ levels favour the transition of some glycolytic enzymes to less-active forms in marine bivalves and consequently support a dormant state of the organism (Brooks \& Storey 1997).

In several cases, however, metabolic depression occurs independent of reduced $\mathrm{pH}_{\mathrm{i}}$ levels (Hand 1998, Pörtner et al. 1998). The full restoration of $\mathrm{pH}_{\mathrm{i}}$ observed during early hypercapnia in adult Mytilus galloprovincialis (Fig. 6) and the long-term maintenance of compensated $\mathrm{pH}_{\mathrm{i}}$ values in juveniles (Fig. 7) also indicate that the reduction in oxygen consumption is not elicited by low $\mathrm{pH}_{\mathrm{i}}$ in the case of $M$. galloprovincialis. The drop in oxygen consumption might rather be associated with low $\mathrm{pH}_{\mathrm{e}}$. In fact, the depressant effect of $\mathrm{CO}_{2}$ in the above-mentioned sipunculid was correlated with the $\mathrm{pH}$ drop in extracellular rather than intracellular fluids (Reipschläger \& Pörtner 1996, Pörtner et al. 1998). The $\mathrm{pH}_{\mathrm{e}}$-dependent modification of oxygen consumption rates seems to be partly medi- ated by inhibition of net proton transport across the cell membrane during acidosis (Reipschläger \& Pörtner 1996, Pörtner et al. 2000).

Further mechanisms may contribute to metabolic depression at reduced values of $\mathrm{pH}_{\mathrm{e}}$. Similarly to observations in Mytilus edulis and Sipunculus nudus (Lindinger et al. 1984, Pörtner et al. 1998), hypercapnia stimulated the excretion of ammonia in $M$. galloprovincialis despite falling rates of oxygen consumption (Fig. 8b), resulting in falling $\mathrm{O} / \mathrm{N}$ ratios. Lindinger et al. (1984) suggested that ammonia excretion may be an important mechanism for acid excretion in $M$. edulis; however, most of the ammonia may be lost by diffusive release of ammonia rather than excretion of ammonium. In any case, increased ammonia release indicates increased use of amino acids or protein as metabolic substrates during long-term hypercapnia. Recent studies of the influence of hypercapnia on amino-acid catabolism conducted in the marine worm S. nudus (Langenbuch \& Pörtner 2002) indicate a close correlation of the degree of extra- and intracellular acidosis with the rate of amino-acid catabolism and ammonia excretion. The enhanced $\mathrm{N}$ catabolism despite low oxygen consumption as seen in the marine worm and in the present study was hypothesized to indicate preferred catabolism of low $\mathrm{O} / \mathrm{N}$ amino acids such as asparagine, glutamine and their dicarboxylic acids. These changes reflect the net formation of metabolic bicarbonate and may thereby support $\mathrm{pH}$ regulation (Langenbuch \& Pörtner 2002).

Moreover, it has been shown that low pH can induce a significant reduction in protein synthesis in aquatic animals (Kwast \& Hand 1996, Reid et al. 1997). The stimulation of amino-acid catabolism in mussels during exposure to hypercapnic conditions may damage their cellular protein pool and contribute to the drop in somatic growth. The latter would also be involved in the reduction in energy turnover during the dormant state, since protein synthesis is an ATP-consuming process. Moreover, compensation of $\mathrm{pH}_{\mathrm{e}}$ by shell bicarbonate during long-term hypercapnia likely slows down shell growth in Mytilus. The results obtained in the present study are therefore in line with the hypothesis that environmental hypercapnia is associated with a decrease in growth performance involving both metabolic depression and reduced shell growth. As shown in Fig. 3, the relationship between shell length and dry weight is identical in normocapnic and hypercapnic mussels, and the mathematic relationships between morphometric characteristics did not differ between the 2 groups of mussels. These observations clearly indicate both a slower rate of shell growth and reduced growth of soft body in hypercapnic mussels (Figs. 1 \& 2). According to the acid-base status of extra- and intracellular fluids in M. galloprovincialis 
such a long term delay in mussel growth seems to be attributed to extracellular rather than intracellular acidosis. Similarly to our results Bamber (1990) reported that shell length of $M$. edulis showed a significant positive correlation with $\mathrm{pH}$, notably at $\mathrm{pH}<7.5$. Moreover, as reported in the same study, the responses of marine bivalves Ostrea edulis, Grassostrea gigas and $M$. edulis to reduced $\mathrm{pH}$ levels in sea water occur by growth suppression, shell dissolution, tissue weight loss and feeding activity suppression. In addition, further reduction of $\mathrm{pH}$ in sea water caused significant mortality among marine bivalves. The percent mortality was positively correlated with the length of time that mussels were exposed to acidic sea water (Bamber 1990). Similarly, Yamada \& Ikeda (2000) reported that the mortality of zooplankton is directly proportional to exposure time at low sea-water $\mathrm{pH}$. In addition, Hinga (2002) has shown that phytoplankton population dynamics is affected by the changes in the $\mathrm{pH}$ of sea water.

Results of other studies of $\mathrm{pH}$ effects in bivalve molluscs showed that some deleterious effects set in at $\mathrm{pH} \approx 7.5$. However, all studies show that marine bivalve molluscs cannot tolerate $\mathrm{pH} \leq 7.0$. A positive correlation between sea-water $\mathrm{pH}$ and growth rate has also been reported for other shallow-living marine organisms (Takeuchi et al. 1997, Ringwood \& Keppler 2002, Shirayama 2002).

In conclusion, the results presented here confirm the statement that a sea-water $\mathrm{pH}<7.5$ (surprisingly close to the lower limits of $\mathrm{pH}$ variability in natural sea water) is harmful at least for marine bivalves. Shell dissolution under modest hypercapnia can facilitate the compensation of temporary acid-base disturbances. However, chronic exposure seems to slow down several physiological processes, resulting in a low rate of mussel metabolism and growth. The latter may finally lead to an increase in mussel mortality, an assumption consistent with other data, which emphasize that shallow-living organisms are generally intolerant to hypercapnia (Knutzen 1981). $\mathrm{CO}_{2}$ effects on marine organisms and their physiology are also relevant in the light of a potential future scenario of atmospheric $\mathrm{CO}_{2}$ disposal into deep water (Pörtner \& Reipschläger 1996, Seidel \& Walsh 2003). As reported, such a process will affect marine ecosystems, and it may have large effects depending on the sensitivity of individual species. In line with our present findings, recent investigations of $\mathrm{CO}_{2}$ effects in a deep-sea echinoid (sea urchin) also indicate that long-term exposure under $\mathrm{CO}_{2}$ disposal scenarios would be fatal if $\mathrm{CO}_{2}$ excursions are sufficiently large enough to initiate shell dissolution (Barry et al. 2002). According to a recent overview of the biological impact of elevated sea-water $\mathrm{CO}_{2}$ concentrations (Pörtner et al. 2004) $\mathrm{CO}_{2}$ itself as well $\mathrm{CO}_{2}$ - related changes in $\mathrm{pH}$ and bicarbonate levels affect molecular, cellular, tissue and whole organism functions, i.e. functions situated at different organizational levels. Those functions affected at lower levels of organization (molecular, etc.) likely integrate into a hierarchical system of $\mathrm{CO}_{2}$ effects, where those found at the highest organizational levels appear most sensitive and are co-defined by the integration of molecular functions and vice versa. The reduction in growth rate as observed here may finally result from such an integrated scenario of $\mathrm{CO}_{2}$ effects. The degree of change observed at water pH 7.3 (growth reduction to $55 \%$ and metabolic depression to $65 \%$ of normocapnic values) suggests that the observed effects set in much before this $\mathrm{pH}$ value is reached and, therefore, much earlier than in the year 2300. A more detailed titration of these effects considering the progressive rise in $\mathrm{CO}_{2}$ levels as expected during the next decades thus awaits further study.

\section{LITERATURE CITED}

Bamber NR (1990) The effects of acidic sea water on three species of lamellibranch molluscs. J Exp Mar Biol Ecol 143:181-191

Barnhart MC (1989) Respiratory acidosis and metabolic depression in dormant invertebrates. In: Malan A, Canguilhem B (eds) Living in the cold. Colloque INSERM/ John Libbey Eurotext, London, p 315-401

Barnhart MC, McMahon BR (1988) Depression of aerobic metabolism and intracellular $\mathrm{pH}$ by hypercapnia in land snails, Otala lactea. J Exp Biol 138:289-299

Barry J, Seidel BA, Drazen J, Tamburr M, Lovera C, Brewer P (2002) Field experiment on direct ocean $\mathrm{CO}_{2}$ sequestration: the response of deep-sea faunal assemblages to $\mathrm{CO}_{2}$ injection at $3200 \mathrm{~m}$ off central California. EOS Trans 83, OS51F-02

Bergmeyer HU, Bergneyer J, Graßl M 1986 (eds) Methods of enzymatic analysis. Verlag Chemie, Weinheim

Booth CE, McDonald DG, Walsh PJ (1984) Acid-base in the mussel, Mytilus edulis. I. Effects of hypoxia and airexposure on hemolymph acid-base status. Mar Biol Lett 5:347-358

Brooks SP, Storey KB (1997) Glycolytic controls in estivation and anoxia: a comparison of metabolic arrest in land and marine molluscs. Comp Biochem Physiol A 118:1103-1114

Caldeira K, Wickett ME (2003) Anthropogenic carbon and ocean $\mathrm{pH}$. Nature 425:365

Cameron JN (1971) Rapid method for determination of total carbon dioxide in small blood samples. J Appl Physiol 31: $632-634$

Cameron JN (1986) Acid-base equilibria in invertebrates. In: Heisler N (ed) Acid-base regulation in animals. Elsevier, New York, p 357-394

Cameron JN (1989) The respiratory physiology of animals. Oxford University Press, New York

Cameron JN, Iwama GK (1987) Compensation of progressive hypercapnia in channel catfish and blue crabs. J Exp Biol 133:183-197

Cancela da Fonseca J (1965) L'outil statistique en biologie du sol. I. Distributions de freqences et tests de signification. Rev Ecol Biol Sol 11:299-332 
Fyhn HJ, Costlow DJ (1975) Anaerobic sampling of body fluids in bivalve molluscs. Comp Biochem Physiol A 52:265-268

Guppy M, Withers P (1999) Metabolic depression in animals: physiological perspectives and biochemical generalizations. Biol Rev 74:1-40

Hand SC (1998) Quiescence in Artemia franciscana embryos: reversible arrest of metabolism and gene expression at low oxygen levels. J Exp Biol 201:1233-1242

Heisler M (1986) Buffering and transmembrane ion transfer processes. In: Heisler N (ed) Acid-base regulation in animals. Elsevier Science Publishers BV, Amsterdam, p 3-47

Heisler M (1989) Interactions between gas exchange, metabolism, and ion transport in animals: an overview. Can J Zool 67:2923-2935

Hinga KR (2002) Effects of $\mathrm{pH}$ on coastal marine phytoplankton. Mar Ecol Prog Ser 238:281-300

Houghton JT, Ding Y, Griggs DJ, Noguer M, van der Linde PJ, Xiaosu D (eds) (2001) Climate change 2001: the scientific basis. IPCC Third Assessment Report: climate change 2001. Cambridge University Press, Cambridge

Jokumsen A, Fyhn JH (1982) The influence of aerial exposure upon respiratory and osmotic properties of haemolymph from two interdital mussels, Mytilus edulis L. and Modiolus modiolus L. J Exp Mar Biol Ecol 61:189-203

Knutzen J (1981) Effects of decreased pH on marine organisms. Mar Pollut Bull 12:25-29

Kwast KE, Hand SC (1996) Oxygen and pH regulation of protein synthesis in mitochondria from Artemia franciscana embryos. Biochem J 313:207-213

Lackner KSA (2003) A guide to $\mathrm{CO}_{2}$ sequestration. Science 300:1677-1678

Langenbuch M, Pörtner HO (2002) Changes in metabolic rate and $\mathrm{N}$ excretion in the marine invertebrate Sipunculus nudus under conditions of environmental hypercapnia: identifying effective acid-base variables. J Exp Biol 205: $1153-1160$

Lindinger MI, Lauren DJ, Mcdonald DG (1984) Acid-base balance in the sea mussel, Mytilus edulis. III. Effects of environmental hypercapnia on intra- and extracellular acid-base balance. Mar Biol Lett 5:371-381

Ormerod B, Angel M (1996) Ocean storage of carbon dioxide. In: Ormerod B, Angel MV (eds) Workshop 2: Environmental impact. International Energy Agency, Greenhouse Gas R\&D Program, Cheltenham, p 9-40

Pörtner HO, Reipschläger A (1996) Ocean disposal of anthropogenic $\mathrm{CO}_{2}$ : physiological effects on tolerant and intolerant animals. In: Massachusetts Institute of Technology and International Energy Agency, Greenhouse Gas R\&D Programme (ed) Ocean storage of $\mathrm{CO}_{2}$ : environmental impact. Massachusetts Institute of Technology, Boston, and International Energy Agency, Greenhouse Gas R\&D Programme, Cheltenham, p 57-81

Pörtner HO, Boutilier RG, Tang Y, Towes DP (1990) Determination of intracellular $\mathrm{pH}$ and $\mathrm{pCO}_{2}$ after metabolic inhibition by fluoride and nitrilotriacetic acid. Resp Physiol 81: 255-274

Pörtner HO, Reipschläger A, Heisler N (1998) Acid-base regulation, metabolism and energetics in Sipunculus nudus as a function of ambient carbon dioxide level. J Exp Biol 201:43-54

Editorial responsibility: Otto Kinne (Editor-in-Chief), Oldendorf/Luhe, Germany
Pörtner HO, Bock C, Reipschläger A (2000) Modulation of the cost of $\mathrm{pH}_{\mathrm{i}}$ regulation during metabolic depression: a ${ }^{31} \mathrm{P}-$ NMR study in invertebrate (Sipunculus nudus) isolated muscle. J Exp Biol 203:2417-2428

Pörtner HO, Langenbuch M, Reipschläger A (2004) Biological impacts of elevated ocean $\mathrm{CO}_{2}$ concentrations: lessons from animal physiology and earth history? J Oceanogr 60:705-718

Rees BB, Hand SC (1990) Heat dissipation, gas exchange and acid-base status in the land snail Oreohelix during shortterm estivation. J Exp Biol 152:77-92

Reid SD, Dockray JJ, Linton TK, McDonald DG, Wood CM (1997) Effects of chronic environmental acidification and a summer global warming scenario: protein synthesis in juvenile rainbow trout (Oncorhynchus mykiss). Can J Aquat Sci 54:2014-2024

Reipschläger A, Pörtner HO (1996) Metabolic depression during environmental stress: the role of extra- versus intracellular $\mathrm{pH}$ in the Sipunculus nudus. J Exp Biol 199: 1801-1807

Ringwood HA, Keppler JC (2002) Water quality and clam growth: Is pH really a non-issue in estuaries? Estuaries 25: 901-907

Roos A, Boron WF (1981) Intracellular pH. Physiol Rev 61: 296-434

Seidel BA, Walsh PJ (2003) Biological impacts of deep-sea carbon dioxide injection inferred from indices of physiological performance. J Exp Biol 206:641-650

Shirayama Y (2002) Towards comprehensive understanding of impacts on marine organisms due to raised $\mathrm{CO}_{2}$ concentration. In: Proceedings of the 5th International Symposium on $\mathrm{CO}_{2}$ fixation and efficient utilization of energy. Tokyo Institute of Technology, Tokyo, p 177-181

Somero GN (1985) Intracellular $\mathrm{pH}$, buffering substances and proteins: imidazole protonation and the conservation of protein structure and function. In: Gilles R, Gilles-Baillien $M$ (eds) Transport processes, iono- and osmoregulation. Springer-Verlag, Berlin, p 454-468

Takeuchi K, Fujioka Y, Kawasaki Y, Shirayama Y (1997) Impacts of high concentrations of $\mathrm{CO}_{2}$ on marine organisms: a modification of $\mathrm{CO}_{2}$ ocean sequestration. Energy Convers Man 38:S337-S341

Truchot JP (1987) Comparative aspects of extracellular acid-base balance. Springer-Verlag, Berlin

Truchot JP, Duhamel-Jouve A (1980) Oxygen and carbon dioxide in the marine intertidal environment: diurnal and tidal changes in rockpools. Resp Physiol 39:241-254

Walsh PJ, Milligan CL (1989) Coordination of metabolism and intracellular acid-base status: ionic regulation and metabolic consequences. Can J Zool 67:2994-3004

Walsh PJ, McDonald DG, Booth CE (1984) Acid-base balance in the sea mussel Mytilus edulis. II. Effects of hypoxia and air-exposure on intracellular acid-base status. Mar Biol Lett 5:359-369

Yamada Y, Ikeda T (1999) Acute toxicity of lowered $\mathrm{pH}$ to some oceanic zooplankton. Plankton Biol Ecol 46:62-67

Zange J, Grieshaber KM, Jans HWA (1990) The regulation of intracellular $\mathrm{pH}$ estimated by ${ }^{31} \mathrm{P}-\mathrm{NMR}$ spectroscopy in the anterior byssus retractor muscle of Mytilus edulis L. J Exp Biol 150:95-109

Submitted: July 17, 2004; Accepted: February 10, 2005

Proofs received from author(s): May 5, 2005 